Canadian Science Publishing

Biochemistry and Cell Biology

Biochimie et biologie cellulaire

\title{
A deletion variant partially complements a porin-less strain of Neurospora crassa
}

\begin{tabular}{|r|l|}
\hline Journal: & Biochemistry and Cell Biology \\
\hline Manuscript ID & bcb-2016-0166.R1 \\
\hline Manuscript Type: & Note \\
\hline Date Submitted by the Author: & 07-Oct-2016 \\
\hline Complete List of Authors: & $\begin{array}{l}\text { Ferens, Fraser; University of Manitoba, Microbiology } \\
\text { Spicer, Victor; University of Manitoba } \\
\text { Krokhin, Oleg; University of Manitoba } \\
\text { Motnenko, Anna; University of Manitoba, Microbiology; University of } \\
\text { Oxford, Biochemistry } \\
\text { Summers, William; University of Manitoba } \\
\text { Court, Deborah; University of Manitoba }\end{array}$ \\
\hline Keyword: & VDAC, mitochondrial porin, Neurospora, LC-MS/MS, alternative oxidase \\
\hline \multicolumn{2}{|c|}{} \\
\hline
\end{tabular}

\section{SCHOLARONE}

Manuscripts 
A deletion variant partially complements a porin-less strain of Neurospora crassa.

Fraser G. Ferens ${ }^{1}$, Victor Spicer ${ }^{2}$, Oleg V. Krokhin ${ }^{3}$, Anna Motnenko ${ }^{1,4}$, William A.T. Summers ${ }^{1}$, and Deborah A. Court ${ }^{1}$.

Departments of ${ }^{1}$ Microbiology and ${ }^{2}$ Physics and Astronomy, University of Manitoba, Winnipeg, MB R3T 2N2, Canada

${ }^{3}$ Department of Internal Medicine \& Manitoba Centre for Proteomics and Systems Biology, University of Manitoba, Winnipeg, MB R3E 3P4, Canada.

${ }^{4}$ Current address: Department of Biochemistry, University of Oxford, Oxford 0X1 3QU, UK.

key words: VDAC, mitochondrial porin, Neurospora, LC-MS/MS, alternative oxidase 


\begin{abstract}
Mitochondrial porin, the voltage-dependent anion channel, plays an important role in metabolism and other cellular functions within eukaryotic cells. To further the understanding of porin structure and function, Neurospora crassa wild-type porin was replaced with a deletion variant lacking residues 238-242 (238porin). 238porin was assembled in the mitochondrial outer membrane, but the steady state levels were only about $3 \%$ of those of the wild-type protein. The strain harbouring 238porin displayed cytochrome deficiencies and expressed alternative oxidase. Nonetheless, it exhibited an almost normal linear growth rate. Analysis of mitochondrial proteomes from a wild-type strain FGSC9718, a strain lacking porin $(\Delta$ Por-1) and that expressing 238porin revealed that the major differences between the variant strains were in the levels of subunits of the NADH:ubiquinone oxidoreductase (complex I) of the electron transport chain, which were reduced only in $\Delta$ Por-1 strain. These, and other proteins related to electron flow and mitochondrial biogenesis, are differentially affected by relative porin levels.
\end{abstract}




\section{Introduction}

Mitochondrial porin forms a highly abundant, voltage-dependent anion-selective channel (VDAC) in the outer membrane of mitochondria. The aqueous channel formed by the 19-stranded $\beta$-barrel (Hiller et al. 2008, Bayrhuber et al. 2008, Ujwal et al. 2008, Gattin et al. 2015, Schredelseker et al. 2014) allows for the passage of small metabolites, thereby mediating efficient introduction of substrates and release of products to and from mitochondria (reviewed by Summers and Court 2010). In artificial membranes, porin exhibits voltage-dependent gating that shifts the pore between a slightly anion-selective open state and a slightly cation-selective, semiclosed state (Benz 1994, Homblé et al. 2012).

Mitochondrial porin has been shown to interact with many other cellular proteins (for example see Roman et al. 2005), including those involved in the regulation of apoptosis in mammalian cells (reviewed by Shoshan-Barmatz and Mizrachi 2012), and as a result the structure and function of porin are of great interest. Human VDAC1 (hVDAC1; Hiller et al. 2008, Bayrhuber et al. 2008), and VDAC2 (hVDAC2, Gattin et al. 2015), mouse VDAC1 (Ujwal et al. 2008) and zebrafish VDAC2 (Schredelseker et al. 2014) each form a novel barrel consisting of 19 anti-parallel transmembrane $\beta$-strands. The structure also contains a $N$-terminal $\alpha$-helix, which in the solved structures resides within the pore, although electrophysiological data using native VDAC have been interpreted to indicate that the N-terminal helix forms part of the barrel (see Colombini 2009 for discussion). Although structural data for non-vertebrate VDAC are not currently available, a 19- $\beta$-strand barrel was suggested for Neurospora crassa porin through secondary structure prediction analyses (Young et al. 2007) that align well with the structures of vertebrate VDAC (Summers and Court 2010, Fig. 1).

Recent work has shown that porin is non-essential for mitochondrial function in N. crassa (Summers et al. 2012). This haploid organism is an obligate aerobe that expresses only one porin isoform, allowing straightforward assessment of the effects of a porin variant on the cell. 
Although strains lacking porin ( $\Delta$ Por) are viable, they exhibit extremely inhibited growth rates and mitochondrial dysfunction, demonstrating the necessity of porin for normal mitochondrial and cellular function (Summers et al. 2012). In this study, to further the understanding of the structure and functions of mitochondrial porin, a deletion variant, 238porin, was examined in vivo.

The 238porin variant contains a five-amino acid deletion (residues: NDRGV, Runke et al. 2006) at positions 238-242 (highlighted region in Fig. 1B), which according to predictions based on the solved structures encompasses the loop or turn between $\beta$-strands 16 and 17 . The corresponding sequence in hVDAC1 and hVDAC2 is NNSSL, and is well conserved in vertebrate VDAC isoforms 1 and 2 (see Schredelseker et al. 2014 for examples). These residues encompass the link between $\beta$-strands 16 and 17 in all models published to date (see above for references). A previous study (Runke et al. 2006) examined various biophysical aspects of $N$. crassa porin deletion variants including 238porin, which inserted into and formed pores in artificial lipid bilayers. This variant was found to have pore properties, such as aqueous channel conductance and gating behaviour, similar to those of the wild-type porin. Therefore, it has the potential to form pores in mitochondria, and was chosen as a starting point for the analysis of the roles of specific segments of VDAC in vivo.

\section{Materials and Methods}

\subsection{2 Strains and Growth Conditions}

The strains of Neurospora crassa used in this study are detailed in Table 1. Strains with FGSC designations were obtained from the Fungal Genetics Stock Center, Kansas City, KS (McCluskey et al. 2010). The generation of the cDNA encoding N. crassa 238porin is described in Runke et al. (2006) and the nomenclature used in therein has been used in the current work. A recombination-based method derived from that used by Colot et al. (2006) was used to introduce 
the 238porin coding sequence into the Neurospora genome. In brief, segments of DNA flanking the native porin gene (NCU04304) in strain FGSC 9720 (Colot et al. 2006), the 238porin cDNA (Runke et al. 2006) and the hygromycin-resistance cassette (Staben et al. 1989) were amplified by PCR using the primers listed in Supplementary Table 1, and used to construct the plasmid shown in Fig. 1A. The transformation cassette was removed from the plasmid by digestion with $P v u I I$, purified and transformed into FGSC 9718 as described in Colot et al. (2006). A hygromycinresistant isolate was obtained and purified by repeated subculturing. The gene replacement in the resulting 238Por strain was confirmed by PCR and DNA sequence analyses of the junctions and internal segments of the 238porin coding sequence. Neurospora cultures were maintained on Vogel's minimal medium (VMM) and linear growth rates were determined in race tubes as described by Davis and De Serres (1970); race tubes were obtained from the FGSC.

\section{Analysis of mitochondria}

Mitochondria were isolated from mycelia grown at $30^{\circ} \mathrm{C}$ in liquid VMM with shaking for $18 \mathrm{~h}$ (FGSC 9718a) or $21 \mathrm{~h}$ (238Por), using the procedure of Harkness et al. (1994). Protein concentrations were determined by a Bradford assay (BioShop, Burlington, ON).

Proteins were analyzed by SDS-PAGE using $12 \%$ acrylamide gels, and transferred to nitrocellulose, according to the manufacturer's instructions (Bio-Rad, Mississauga, ON). Primary antibodies against $N$. crassa porin, Tom 40 and Tom 70 were kindly provided by Drs. Roland Lill and Walter Neupert, Universität München. The secondary antibody used was mouse $\alpha$-rabbitIgG-alkaline phosphatase (Sigma-Aldrich, Oakville, ON). Membrane bound complexes were isolated from membranes by resuspending mitochondria (100 $\mu$ g protein) in $50 \mu 1$ 1\% (w/v) n-Dodecyl $\beta$-D-maltoside (DDM) and incubating on ice for 30 min followed by microcentrifugation at $13,000 \mathrm{rpm}$ for $30 \mathrm{~min}$ to remove insoluble material (Summers et al. 2012) and the TOM complex was detected using antibodies against TOM40 (Sherman et al. 2006). Complexes were analyzed by Red-Native-PAGE in the presence of Ponceau S (Drab et al. 2011) 
using a 6\%-13\% acrylamide gradient and western blotting. An in-gel NADH dehydrogenase activity assay was performed as described (Calvaruso et al. 2008).

Cytochrome spectra were determined as previously described (Summers et al. 2012); the reduced minus oxidized difference spectrum is presented (Rifkin and Luck 1971). Expression of alternative oxidase was confirmed as described by Summers et al. (2012), using an Oxygraph-2k (Oroboros Instruments, Innsbruck, Austria).

For imaging of mitochondria, $N$. crassa cultures were grown on solid VMM for 12-16 hours at $30^{\circ} \mathrm{C}$. Staining with $0.1 \mathrm{ng} / \mathrm{ml}$ of MitoTracker Green FM (Life Technologies, Burlington ON) was performed as described by (Wideman et al. 2010), except that hyphae were grown directly on the microscope slide. Images were collected with a Zeiss Observer Z1 inverted microscope (Carl Zeiss Microscopy GmbH, Göttingen, Germany).

\section{Proteomic Analysis of Mitochondria}

Crude mitochondrial samples were prepared from $N$. crassa strains as above. To avoid any damage to the mitochondrial outer membranes and loss of intermembrane space proteins caused by further purification of mitochondria, the samples were utilized directly in this state. The proteomic analysis was conducted as described (Gungormusler-Yilmaz et al. 2014), using liquid chromatography (LC) and tandem mass spectroscopy (MS/MS). The resulting data sets contained many non-mitochondrial protein contaminants due to the use of crude mitochondrial preparations. These contaminant proteins inherently vary in abundance between samples and therefore were removed from the data sets prior to analysis to avoid skewing the data. To identify mitochondrial proteins in the data sets a reference set of mitochondrial proteins was constructed as follows: i) proteins predicted from genes annotated as "mitochondrial" in the Broad Institute's N. crassa genome database (http://www.broadinstitute.org/annotation/genome/neurospora/GenomesIndex.htm), ii) N. crassa proteins annotated as mitochondrial in the UniProt database (http://www.uniprot.org/), iii) 
proteins known to reside in the mitochondrial outer membrane of N. crassa (Schmitt et al. 2006) and iv) any detected protein sequence scoring a mitochondrial probability $\geq 0.9$ via the TargetP subcellular localization prediction server (Emanuelsson et al. 2000).

The resulting data sets of mitochondrial proteins were used to identify differential expression of proteins in the $N$. crassa VDAC mutants. $\log _{2}$ difference values were calculated for each pair of proteins and each set of values was normalized to generate a mean near zero and standard deviation near one. $z$-scores were calculated for proteins detected in both the wild-type and mutant strains. A minimum of $95 \%$ confidence was used to identify proteins that have differences in expression between two strains $(-1.96>z>1.96$, Gungormusler-Yilmaz et al. 2014). These data are presented in Supplementary Tables 2 ( $\Delta$ Por-1 vs. wild-type); 3 (238Por vs. wild-type) and 4 ( $\triangle$ Por-1 vs. 238Por). This approach focuses on the population of differences in expression, rather than the absolute degrees of difference, and is used because the sensitivity of cells to the levels of each protein is unknown. Protein functional data was extracted from the Clusters of Orthologous Groups database (COG; http://www.ncbi.nlm.nih.gov/COG/) and the Kyoto Encyclopedia of Genes and Genomes databases (KEGG; http://www.genome.jp/kegg/).

\section{Results and Discussion}

In order to assess the in vivo function of 238porin, a cDNA coding sequence (Runke et al. 2006), linked to an upstream hygromycin-resistance cassette (Fig. 1A) was used to replace the wild-type porin gene in N. crassa. The resulting strain, 238Por, harbours a very low level of the variant (Fig. 2 and Table 4), indicating that the molecule either is not expressed efficiently at the transcriptional or translational levels, and/or is not effectively targeted to or assembled in the mitochondrial outer membrane (MOM). In mitochondria, 238porin is resistant to externally added protease (data not shown), suggesting that the small amount present is correctly assembled (see Court et al. 1996). 
Unexpectedly, the low levels of 238porin in mitochondria were not linked to significant growth defects (Table 2). The 238Por strain grew at more than $85 \%$ of the wild-type (FGSC 9718) rate at both $22^{\circ} \mathrm{C}$ and $30^{\circ} \mathrm{C}$. This is in contrast to the severe reduction in growth rates observed in $\Delta$ Por mutants, particularly at lower temperatures (Summers et al. 2012, Table 2). Thus, the very low levels of 238porin variant are able to partially complement the lack of wildtype porin.

One characteristic of the porin-less strains of $N$. crassa is a deficiency in the cytochromes assembled with mitochondrially-encoded polypeptides (Summers et al. 2012); these types of defects also arise when mitochondrial translation is blocked (Descheneau et al. 2005), and in other nuclear and mitochondrial mutants of $N$. crassa (for example see Rifkin and Luck 1971). Similarly, the 238Por strain displays deficiencies in cytochromes $a a_{3}$ and $b$, and an increased level of cytochrome $c$ (Fig. 3). It also displays cyanide-resistant, SHAM-sensitive oxygen consumption (Table 2), characteristic of strains expressing alternative oxidase (Lambowitz and Slayman 1971).

In principle, these differences between wild-type and 238Por cells could reflect low levels of porin, expression of a mutant porin, or a combination of the two. Attempts were made to generate a strain expression low levels of wild-type porin. Reduction of porin to $30-60 \%$ of wildtype levels was not associated with any detectable changes in growth rate, cytochrome profile, or expression of alternative oxidase (S. Shuvo and D. Court, personal communication), but very low levels of porin corresponding to those in 238 Por $(<5 \%)$ were not achieved. Given the ability of 238Por to generate an apparently wild-type pore in artificial membranes, the defects in 238Por may be most reflective of the low amount of porin. Nonetheless, it was predicted that further analysis of 238Por variant would reveal cellular changes responsible for almost wild-type growth rates in the absence of a normal mitochondrial bioenergetics. To that end, the proteomes of 238Por, $\Delta$ Por-1 and Por-WT strains were assessed. 


\section{1-Dimensional LC MS/MS analysis of the mitochondrial proteomes}

Proteins were extracted from partially purified mitochondria and subjected to LC MS/MS. Peptides from a total of 1102 different proteins were detected, and slightly more than half of the proteins identified from each strain were predicted to reside in mitochondria (summarized in Table 3). The proteomic approach used in the current study detected a similar number of proteins (509) as was detected from $N$. crassa mitochondria through the use of iTRAQ from sucrosegradient purified organelles (260, Keeping et al. 2011 and 488, Summers et al. 2012). In the latter study, there were a number of intermembrane space proteins that were present in significantly reduced amounts in $\Delta$ Por- 1 , in spite of relatively normal levels of the corresponding mRNA (Summers et al. 2012). These proteins include TIM8, ketol-acid reductoisomerase, nucleoside diphosphate kinase-1, adenylate kinase, and ubiquinone cytochrome $c$ reductase hinge. They were not reduced in the $\Delta$ Por-1 organelles used in the current study (Supplementary Table 2). Thus it appears that the outer membranes of $\Delta$ Por-1 organelles were disrupted during the sucrosegradient purification step in the iTRAQ studies.

The outer membrane proteome was well represented in the current study; 29 of the 30 proteins identified by Schmitt et al. (2006) in purified outer membranes were detected in the current study in wild-type mitochondria (Table 3). The exception was a mitochondrial import protein 1 (MIM1, NCU01101), a 130-amino acid protein required for assembly of TOM20 into the outer membrane (Popov-Celeketic et al. 2008). In contrast to the previous iTRAQ study (Summers et al. 2012), TOB55, a $\beta$-barrel in the topogenesis of mitochondrial outer membrane $\beta$ barrels (TOB) complex was detected in the current work, and there was a non-significant reduction its levels in $\Delta$ Por- 1 and 238 Por ( $\log _{2}$ ratios of -0.3 and -0.5 , respectively). Thus, as for the case for another $\beta$-barrel, TOM44 of the translocase of the outer membrane (see Summers et al. 2012 and Fig. 2), upregulation of the TOB55 $\beta$-barrel was not increased as a mechanism for 
compensating for the absence of VDAC. The remaining predicted MOM $\beta$-barrel, MDM10 has yet to be detected in any large scale proteomic analysis.

\section{Electron transport chain}

Both $\Delta$ Por-1 and 238Por display defects in cytochromes associated with mitochondrially encoded polypeptides and express alternative oxidase (Fig. 3 and Table 2). Proteomic analysis further revealed defects in NADH:Ubiquinone oxidoreductase (complex I) in $\Delta$ Por-1 (Table 4), which are supported by changes in the high molecular weight complexes detected by in-gel NDAH dehydrogenase assays (Fig. 4)

One of the main differences between the proteomes of $\Delta$ Por-1 and 238Por mitochondria is in the levels of subunits of complex I, which oxidizes NADH and translocates hydrogen ions into the intermembrane space. None of the 27 subunits of complex I detected were present in significantly reduced levels $\left(\log _{2}\right.$ difference $\left.<-1.6\right)$ in 238Por (Supplementary Table 3 ), suggesting that this complex was functional. In contrast, in $\Delta$ Por-1 mitochondria, the levels of the 9.8- and 20.1-kDa subunits (NCU04781 and NCU09460) were significantly lower than in wildtype (Table 4), and levels of these proteins and the 40-kDa subunit were significantly different when the data from the two mutant strains were compared (Supplementary Table 4). A nuo9.8 mutant lacking the former subunit fails to assemble the membrane-bound and peripheral arms of complex I (Marques et al. 2003), suggesting that assembly of this complex would be impaired in $\Delta$ Por-1. In fact, fifteen of the 27 other complex I subunits detected were present at levels 2.5 - to 5-fold lower than in wild-type, although these differences were statistically insignificant (see Supplementary Table 2). The differences in complex I activity are supported by the NADH dehydrogenase in-gel assay (Fig. 4). Neurospora expresses four alternative NAD(P)H dehydrogenases allowing bypass of complex I, oxidizing $\mathrm{NAD}(\mathrm{P}) \mathrm{H}$ without proton translocation. Of these, NDE2 (Carneiro et al. 2004) and NDI1 (Duarte et al. 2003) are essential for the viability in the absence of functional complex I. The relative levels of these proteins were not significantly 
changed in the $\triangle$ Por-1 mitochondria. Another alternative enzyme, NDE1, was unchanged and NDE3 (Carneiro et al. 2007) was not detected. Thus, the reduced levels of several subunits of the NADH dehydrogenase complex are not associated with overexpression of the alternative dehydrogenases in $\Delta$ Por-1 mitochondria and the defects in complex I may contribute to the very slow growth of $\Delta$ Por-1 in comparison to 238Por (Table 2).

The reduction in complex I subunits in $\Delta$ Por-1, and the reduced levels of cytochromes $b$ and $a a_{3}$ in both variant strains might contribute to suboptimal ratios of NAD(P)H/NAD(P), leading to changes in expression of proteins that impact these ratios. The increased levels of an NAD(P)H transhydrogenase (NCU01140, Gameiro et al. 2013), and a short chain dehydrogenase (NCU02097) in both strains (Tables 4 and 5) may be involved in optimizing NAD ${ }^{+} / \mathrm{NADH}_{\text {levels, }}$ particularly in $\Delta$ Por-1. Both variant strains harbour relatively high levels of an annotated rubredoxin reductase (NCU05850, Table 5). It has been identified as a homologue of apoptosisinducing factor (Carneiro et al. 2012), an oxidoreductase that may be expressed in response to abnormal $\mathrm{NAD}^{+} / \mathrm{NADH}$ ratios.

There are no obvious differences between the variant and wild-type strains in terms of the nuclear-encoded co-enzyme Q: cytochrome $c$ oxidoreductase (complex III) and cytochrome $c$ oxidase (complex IV) proteins that were detected, and the mitochondrially encoded proteins associated with cytochromes $a a_{3}$ in complex IV and $b$ in complex III were not detected in any mutant strain in this and other studies (Summers et al. 2012, Keeping et al. 2011). Two proteins related to biogenesis of the electron transport chain, OMS1 (NCU04764, Lemaire et al. 2004) and OXA2 (Funes et al. 2004) are increased in $\Delta$ Por-1 (Table 4 and Supplementary Table 2), indicating a response at the level of the proteome are related to the assembly of these complexes. As expected in cells with defective electron transport chains (Lambowitz and Slayman 1971), cyanide-resistant alternative oxidase (AOD) activity was detected in both variant strains (Table 2) and both AOD-1 and AOD-3 proteins were detected in the $\triangle$ Por-1 proteome but not that of the 
wild-type (Supplementary Table 2). However, transcription of aod-1 is induced in N. crassa treated with chloramphenicol, while that of aod-3 is not (Tanton et al. 2003), suggesting that the two genes are regulated independently, and the inducers for both are present in $\Delta$ Por- 1 . However, alternative oxidase activity is not observed in aod-1 mutants (discussed in Tanton et al. 2003), suggesting that the AOX-3 polypeptide detected in this study is non-functional. In spite of the cyanide-resistant respiration observed, neither alternative oxidase protein was detected in 238Por, suggesting that their levels were sufficient for biological activity but were below detection by the methods used.

In terms of the $\mathrm{F}_{1} \mathrm{~F}_{\mathrm{o}}-\mathrm{ATP}$ synthase (complex V), in $\Delta$ Por-1 (Tables 4 and 7), there was a higher level of a protein (NCU03558) that is similar to the $\varepsilon$-subunit (Atp15p, Tetaud et al. 2014) and an inner membrane protease involved in maturation of subunit 6 (NCU00107, ATP-23, Zeng et al. 2007) was less abundant in 238Por (Table 5) and not detected in $\Delta$ Por-1. In both variant strains, there was a significant deficit in the putative e-subunit of the $\mathrm{F}_{\mathrm{o}}$ subcomplex (NCU09143, Tables 4 and 5), which will be discussed below.

\section{Oxidative stress}

Oxidative stress is a predictable outcome in cells lacking complete electron transport chains and several of the differences between the proteomes of the wild-type and variants indicate direct or indirect responses to oxidative stress. Both variants express higher levels of alternative oxidase, which acts on reduced ubiquinone (Maxwell et al. 1999) and a Zn-dependent alcohol dehydrogenase (NCU09285, MIG-6, Tables 4 and 5, Summers et al. 2012). Expression of this open reading frame is induced by menadione. Only 238Por showed an increased levels of the protein predicted to encode an atypical 2-Cys peroxiredoxin (NCU06880), associated with resistance to hydrogen peroxide in mammalian cells (Seo et al. 2000).

In contrast, several proteins linked to reducing oxidative stress are in lower levels in one or both of the variant strains, including proline oxidase (NCU02936, Goncalves et al. 2014) and 
the thiamine thiazole synthase (Chatterjee et al. 2011). Perhaps unexpectedly, there is over 8-fold less of the latter enzyme (NCU06110; CyPBP37) in $\triangle$ Por-1 than in the wild-type and 238Por strains, respectively (Table 4 and Supplementary Table 4). Another thiamine biosynthetic enzyme, NMT-1 (NCU09345) is drastically reduced only in $\triangle$ Por-1 (Table 4) and has been implicated in protection against oxidative stress in yeast (Franken et al. 2008). Finally, lipoic acid has antioxidant activity (discussed in Petersen Shay et al. 2008) and lipoic acid synthase (NCU00565) is reduced only in 238Por only (Table 5). Other impacts of reduced lipoic acid levels are discussed with respect to the TCA cycle and heme biosynthesis below (Fig. 7).

Both strains show evidence of increased responses to misfolded proteins, which could result from the effects of reduced ATP levels on chaperone activity. $\Delta$ Por-1 and 238Por have low-level overexpression of the proteolytic subunit of the Clp protease (NCU4578, Tables 4 and 5), which participates in the mitochondrial unfolded protein response (reviewed by Hamon et al. 2015). Aspartyl aminopeptidase (NCU00122) also is present in higher levels in both variant strains, and aminopeptidases may "moonlight" as chaperones (Malki et al. 2005, Lee and Zhang 2009, Scranton et al. 2012). Three other proteases, carboxypeptidase Y (NCU00477), the mitochondrial AAA ATPase (NCU05459), and the intermembrane space AAA protease IAP-1 (NCU03359) are present in elevated levels in $\Delta$ Por-1 compared to 238Por (Supplementary Table 4). The latter protease is part of the mitochondrial protein quality control system (Klanner et al. 2001), again suggesting increased protein misfolding in $\Delta$ Por-1.

Several of the differentially expressed proteins are linked to the TCA cycle, through the generation of cofactors or substrates, or utilization of TCA intermediates as substrates (Fig. 7). In mitochondria, the pyruvate dehydrogenase complex (PDC) converts pyruvate into acetyl-CoA, which can then enter the TCA cycle (Fig. 7A). Lipoic acid is a PDC cofactor (Morikawa et al. 2001). Increased levels of pyruvate dehydrogenase kinase (PDK, NCU03796), which inactivates PDC (Zhang et al. 2014), and reduced lipoic acid synthase (LAS, NCU00565) in 238Por (Table 
5) suggest lower levels of PDC activity in 238Por, which might optimize ratios of its substrates (pyruvate, $\mathrm{NAD}^{+}$and coenzyme $\mathrm{A}$ ) and products (acetyl-CoA and $\mathrm{NADH}^{+}$and $\mathrm{H}^{+}$). A second potential link to acetyl-CoA production is through the 3-ketoacyl CoA thiolyase (NCU05558), which participates in both fatty acid degradation and fatty acid elongation. The slightly higher levels of acyl-CoA synthase (NCU03929) might drive higher levels of fatty acid biosynthesis and ensure release of acetyl-CoA. Finally, the carnitine shuttle is involved in movement of acetyl groups between peroxisomes and mitochondria (reviewed by Strijbis et al. 2008). In $\Delta$ Por-1, the lower levels of trimethyllysine dioxygenase (TMLD, NCU03802), involved in carnitine biosynthesis, could potentially influence the shuttle and the acetyl-CoA levels in the organelle.

Several proteins present in lower levels only in $\Delta$ Por-1 are linked to intermediates of the TCA cycle (Fig. 7B). TMLD consumes $\alpha$-ketoglutarate and generates succinate, bypassing a step that reduces $\mathrm{NAD}^{+}$. The lower levels of a putative succinate/fumarate mitochondrial transporter (Sfc1p homologue, NCU08561) would potentially drive matrix succinate levels lower, without increasing levels of ROS via a backlog of reduced ubiquinone. The yeast homologue of the transporter, Sfc1p (or Acrlp) is required for acetyl-CoA synthetase activity (Fernandez et al. 1994) again linking changes in $\Delta$ Por-1 with reduced acetyl-CoA levels.

Both mutant strains harbour lower levels of 5-aminolevulinate synthase (ALAS, NCU006189, Tables 4 and 5), which is involved in heme biosynthesis (reviewed by Hunter and Ferreira 2011) and may be a response to reduced heme requirements due to reduced levels of cytochromes $a a_{3}$ and $b$ in the porin variants. Reduction in ALAS activity would also prevent diversion of succinyl-CoA from the TCA cycle (Fig. 7B). Conversely, $\alpha$-ketoglutarate dehydrogenase (KGD), which generates succinyl-CoA, requires lipoic acid ((Schonauer et al. 2009)) and lipoic acid synthase is reduced in 238 Por.

\section{Mitochondrial biogenesis}


The translocase of the outer membrane (TOM complex) recognizes signals in mitochondrial preproteins and translocates the polypeptides across the outer membrane (reviewed in Dukanovic and Rapaport 2011). The stability of the TOM complex is reduced in $\Delta$ Por mitochondria, as indicated by the increased migration rate of Tom40-containing complexes during non-denaturing PAGE (Summers et al. 2012, Fig. 5). In contrast, the complex in 238Por migrates similarly to that of the wild-type strain, indicating that the small amount of 238Porin is sufficient for maintenance of the complex.

Depletion of mitochondrial porin also is associated with altered mitochondrial morphology (Summers et al. 2012). Staining of whole mitochondria with MitoTracker revealed similar morphology for 238Por and wild-type organelles (Fig. 6). However, there appeared to be a lower number of well-stained organelles per hyphal tip, and those observed generally were larger in the 238Por cells. Under the staining conditions used, long string-like mitochondria were not observed in hyphal tips in the wild-type.

With respect to different morphology, a potential Mdm33p homologue (NCU06546) is required for normal morphology and distribution of mitochondria (mdm; Messerschmitt et al. 2003 ) is relatively more abundant in $\triangle$ Por-1 and 238Por strains (Tables 4 and 5). FZO1 encoded by uvs-5 (NCU00436) is a mitofusin homologue in the outer membrane (Schmitt et al. 2006) is more than 8-fold reduced in $\Delta$ Por-1 mitochondria (Table 4), but was present in almost normal levels in 238Por organelles. This defect in $\Delta$ Por-1 may contribute to the small mitochondria seen $\Delta$ Por-1 strains (Summers et al. 2012), as uvs-5 strains have fragmented mitochondria (Kurashima et al. 2013).

In both strains, there was a significant deficit in the putative e-subunit (NCU09143) of the $\mathrm{F}_{\mathrm{o}}$ ATPase synthase subcomplex (Tables 4 and 5). This subunit, Atp21p in S. cerevisiae, is involved in the formation of monomers of the $\mathrm{F}_{1} \mathrm{~F}_{\mathrm{o}}$-ATP synthase that are competent for dimerization (Wagner et al. 2009) and the dimers in turn appear to contribute to the curvature of the inner membrane (Davies et al. 2012). The mitochondrial organizing structure (MitOS) of the 
inner membrane is proposed to interact with the ATP synthase dimers and contribute to the development of normal morphology. The putative homologue (NCU01024) of one component of the yeast MitOS, Aim5p, is expressed at lower levels in $\Delta$ Por-1 mitochondria (Table 4), perhaps contributing to the abnormal morphology. Interestingly, porin is linked to MitOS through genetic interactions (Hoppins et al. 2011) although the nature of the interaction is unknown.

Two variably expressed proteins participate in synthesis of the non-protein components of the outer membrane. The sterol 24-C methyltransferase (NCU03006) is involved in ergosterol biosynthesis, and is present at 3.0- to 4.6-fold higher levels in both strains. The full extent of the impact of porin defects on sterol biosynthesis is not known because the other enzymes in the pathway from zymosterol to ergosterol (ERG-2, ERG-3, ERG-5) were not detected in any strain, and ERG-6 was detected only in the wild-type strain. An enzyme involved in fatty acid biosynthesis, 3-oxoacyl-(acyl-carrier-protein) reductase (NCU01092) was not detected in the wild-type strain, but was present in almost 8-fold higher levels in $\Delta$ Por-1 (Table 4).

\section{Conclusions}

238porin is present in relatively low levels in the outer membrane, but nonetheless partially complements a porin-less strain of Neurospora. Its presence is associated with almost wild-type growth rate, although 238Por expresses alternative oxidase and suffers defects in the electron transport chain. The proteomic studies revealed links to altered electron flow, NADH metabolism and mitochondrial morphology in both $\Delta$ Por-1 and 238Por strains. The strain expressing 238Por appears to contain higher levels of complex I of the ETC, and the carbon flow through the TCA cycle in these cells may be different from that in $\Delta$ Por- 1 organelles. Thus, the cellular response to the presence of a low level of 238Por allows more rapid hyphal growth.

\section{Acknowledgements}

https://mc06.manuscriptcentral.com/bcb-pubs 
This work was supported by a Discovery Grant from the Natural Sciences and Engineering Research Council (NSERC) of Canada to D.A.C. F.F. acknowledges support from the Faculties of Science and Graduate Studies at the University of Manitoba. A.M. was supported by an NSERC PGS-M award, and both A.M. and W.A.T.S. received funding from the Faculty of Science. We thank Mr. Sabbir Rahman Shuvo, Dept. of Microbiology, for assistance with microscopy and alternative oxidase measurements, and for valuable discussions. We also thank Dr. Jason Treberg and Mr. Andre Dufresne, Department of Biological Sciences, for assistance with alternative oxidase measurements, and fluorescence microscopy, respectively.

\section{Figure Legends}

Figure 1. Porin variant used in this study. A) Schematic diagram of the construct used to replace the wild-type porin gene to create the 238porin strain. The hygromycin-resistance cassette $\left(\mathrm{HygB}^{\mathrm{R}}\right)$ and the flanking promoter and transcription termination regions were obtained from pCNS44 (Staben et al. 1989). The 238por cDNA was amplified from cloned DNA described in Runke et al. (2006). B) Model of wild-type and 238porin. The structures of wild-type N. crassa porin (left panel, P07144) and 238porin (right panel, Runke et al. 2006) were predicted using Phyre $^{2}$ (Kelley and Sternberg 2009) and the human VDAC1 structure (left panel, Hiller et al. 2008, PDB 2K4T). The residues absent from 238porin are indicated in red in the wild-type structure, and the shortened $\beta$-strands resulting from the absence of residues 238-242 are indicated by the arrow in the 238por structure. Images were created in the PyMOL Molecular Graphics System, Version 1.7.4.

Figure 2. Western blot analysis of wild-type (Por-WT) and 238por-containing mitochondria. 30 $\mu \mathrm{g}$ of mitochondrial protein from each strain were analyzed by western blotting with antibodies against the proteins indicated below each panel. 
Figure 3. The reduced minus oxidized difference spectra obtained from wild-type (Por-WT), 238por, and $\Delta$ Por-1 mitochondria. Peaks representing absorbance by cytochromes $c, b$, and $a / a_{3}$ are indicated.

Figure 4. Red-Native PAGE of DDM-solubilized mitochondrial membrane complexes. A) In-gel NADH dehydrogenase activity assay. B) The same gel stained with Coomassie Brilliant Blue. Arrows indicate bands corresponding to complex I. The intensity of the lower bands of the Coomassie-stained gel were used to confirm that similar amounts of DDM-solubilized material were present in each lane of the gel.

Figure 5. Western blot detection of the Translocase of the Outer Membrane (TOM) complex from Red-Native PAGE of DDM-solubilized mitochondrial membrane complexes. Antibodies against the TOM complex 40-kDa subunit (TOM40) were used to identify the TOM complex.

Figure 6. Fluorescence microscopy. Hyphae of wild-type (left) and 238Por (middle) and $\Delta$ Por-1 (right) were stained with MitoTracker and observed at 1000x magnification. 
Figure 7. Connections among proteins present in different relative amounts in 238por and $\Delta$ Por-1 mitochondria. A) Mitochondrial proteins. Proteins present in relatively high or low amounts are indicated by arrows directed upward or downward, respectively, in split boxes referring to 238Por (left) and $\Delta$ Por-1 (right). In the case of enzymes, the reactions they catalyze are represented by thin or thick arrows if the proteins are in low or high levels, respectively. The blunt arrow between PDK and PDC indicates an inhibitory interaction; all others are positive effects. The dotted line linking TMLD and carnitine in peroxisomes indicates that the mitochondrial enzyme TMLD is required for synthesis of carnitine, which participates in the carnitine shuttle between mitochondria and peroxisomes. The dotted arrow denotes an effect of Sfc1p on the activity of AcCoA synthetase as described in the text. PDC, pyruvate decarboxylase; PDK, PDC kinase; AcCoA synthase, acetyl-coenzyme A synthase; Carn, carnitine; ka-CoA, 3-ketoacetyl-CoA; TMLD, trimethyllysine dioxygenase.

B) Links between differentially expressed proteins and the TCA cycle in 238porin. The TCA cycle is indicated by double arrows linking substrates/products (boxes). Reduction in lipoic acid synthase (LAS) levels, could reduce the amounts of lipoic acid (grey diamond), a cofactor of $\alpha$-ketoglutarate dehydrogenase (KGD, speckled circle), potentially decreasing levels of succinylCoA. ALAS, 5-Aminolevulinate Synthase. For references, see text. 
Tables

Table 1. Neurospora crassa strains utilized and their respective genotypes

\begin{tabular}{|c|c|c|}
\hline Strain & Relevant Genotypes & Reference \\
\hline FGSC 9718 & mus-51::bar mat a & Colot et al. 2006 \\
\hline FGSC 9720 & mus-52::bar his-3 mat A & Colot et al. 2006 \\
\hline 238Por (FGSC 9718 background) & 238por hph ${ }^{+}$ & This work \\
\hline$\Delta$ Por-1 (FGSC 9718 background) & $\Delta p o r 1:: h p h^{+}$ & $\begin{array}{l}\text { Summers et al. } \\
2012\end{array}$ \\
\hline
\end{tabular}

Table 2. Linear growth rates and cyanide-resistant respiration of Neurospora crassa strains on Vogel's minimal medium

\begin{tabular}{|l|c|c|c|c|c|}
\hline & \multicolumn{2}{|c|}{ Linear Growth Rates } & \multicolumn{2}{c|}{ Relative $\mathbf{O}_{2}$ consumption (\%) } \\
\hline Strain & $\begin{array}{c}\mathbf{2 2}^{\circ} \mathbf{C}(\mathbf{c m} / \text { day) } \\
\text { [percentage of } \\
\text { wild-type rate] }\end{array}$ & $\begin{array}{c}\mathbf{3 0}^{\circ} \mathbf{C}(\mathbf{c m} / \mathbf{d a y}) \\
\text { Ipercentage } \\
\text { of wild-type } \\
\text { rate] }\end{array}$ & $\begin{array}{c}\text { No } \\
\text { additions }\end{array}$ & With KCN & $\begin{array}{c}\text { With } \\
\text { SHAM }^{\mathbf{a}}\end{array}$ \\
\hline FGSC 9718 & $7.8 \pm 0.4[100]$ & $\begin{array}{c}11.4 \pm 0.3 \\
{[100]}\end{array}$ & 100 & 10.2 & $\mathrm{n} / \mathrm{d}^{\mathrm{b}}$ \\
\hline 238Por & $6.9 \pm 0.1[88]$ & $9.8 \pm 0.2[86]$ & 100 & 90.3 & 3.2 \\
\hline$\Delta$ Por-1 & $1.3 \pm 0.3[17]$ & $3.2 \pm 1.4[28]$ & 100 & 95.6 & 12.0 \\
\hline
\end{tabular}

${ }^{\mathrm{a}}$ SHAM, Salicylhydroxamic acid

${ }^{\mathrm{b}} \mathrm{n} / \mathrm{d}$, not detected

Table 3. Protein identification by LC-MS/MS. See Supplementary Tables 2-4 for details

\begin{tabular}{|l|c|c|c|}
\hline Strain & $\begin{array}{l}\text { Total } \\
\text { proteins }\end{array}$ & $\begin{array}{l}\text { Predicted } \\
\text { mitochondrial } \\
\text { proteins }\end{array}$ & $\begin{array}{l}\text { OM } \\
\text { proteins } \\
\text { (of 30) }\end{array}$ \\
\hline FGSC 9718 & 965 & 546 & 29 \\
\hline 238Por & 977 & 548 & 28 \\
\hline$\Delta$ Por-1 & 922 & 542 & 28 \\
\hline
\end{tabular}

${ }^{\mathrm{a}}$ Of the proteins detected in isolated outer membranes of N. crassa (Schmitt et al. 2006) 
Table 4. Proteins detected in altered levels in $\Delta$ Por-1 mitochondria. Data are taken from Supplementary Table 3.

Elevated in $\Delta$ Por-1

\begin{tabular}{|c|c|c|c|c|}
\hline Accession Number & Protein Description & $\begin{array}{l}\text { Expression } \\
\text { Difference } \\
\left(\log _{2}\right)\end{array}$ & COG Group & $\begin{array}{c}\text { Additional Descriptions } \\
\text { (KEGG) }\end{array}$ \\
\hline NCU03558 & Hypothetical protein & 3.35 & None & $\begin{array}{c}\text { Eukaryotic F-type ATPase } \\
\varepsilon \text {-subunit }\end{array}$ \\
\hline NCU01140 & $\begin{array}{c}\text { NAD }(\mathrm{P}) \\
\text { Transhydrogenase }\end{array}$ & 2.94 & $\begin{array}{c}\text { Energy production and } \\
\text { conversion }\end{array}$ & None \\
\hline NCU05850 & $\begin{array}{l}\text { Rubredoxin-NAD } \\
\text { Reductase }\end{array}$ & 2.63 & $\begin{array}{c}\text { General function prediction } \\
\text { only }\end{array}$ & $\begin{array}{c}\text { Similar to pyridine } \\
\text { nucleotide-disulphide } \\
\text { oxidoreductase }\end{array}$ \\
\hline NCU06546 & Hypothetical Protein & 2.36 & None & $\begin{array}{l}\text { K17983 sensitive to high } \\
\text { expression protein } 9\end{array}$ \\
\hline NCU05495 & $\begin{array}{l}\text { CVNH Domain- } \\
\text { Containing Protein }\end{array}$ & 2.29 & None & None \\
\hline NCU00865 & $\begin{array}{l}\text { Oxalate Decarboxylase } \\
\text { OxdC }\end{array}$ & 2.12 & $\begin{array}{l}\text { General function prediction } \\
\text { only }\end{array}$ & None \\
\hline NCU01650 & Hypothetical Protein & 1.83 & None & $\begin{array}{l}\text { Large subunit ribosomal } \\
\text { protein MRP49 }\end{array}$ \\
\hline NCU00122 & Aspartyl Aminopeptidase & 1.82 & $\begin{array}{c}\text { Amino acid transport and } \\
\text { metabolism }\end{array}$ & None \\
\hline NCU04578 & $\begin{array}{l}\text { ATP-Dependent Clp } \\
\text { Protease Proteolytic } \\
\text { Subunit }\end{array}$ & 1.65 & $\begin{array}{l}\text { Intracellular trafficking, } \\
\text { secretion, and vesicular } \\
\text { transport }\end{array}$ & None \\
\hline NCU04764 & Hypothetical Protein & 1.59 & None & Methyltransferase OMS1 \\
\hline \multicolumn{5}{|l|}{ Reduced in $\Delta$ Por-1 } \\
\hline NCU03802 & $\begin{array}{l}\text { Trimethyllysine } \\
\text { Dioxygenase }\end{array}$ & -3.05 & None & None \\
\hline NCU05338 & Hypothetical Protein & -3.22 & None & None \\
\hline NCU08561 & $\begin{array}{c}\text { Succinate/Fumarate } \\
\text { Mitochondrial Transporter }\end{array}$ & -3.36 & None & None \\
\hline NCU01633 & $\begin{array}{c}\text { Hexose Transporter } \\
\text { HXT13 }\end{array}$ & -3.4 & None & $\begin{array}{c}\text { Similar to hexose } \\
\text { transporter }\end{array}$ \\
\hline NCU02564 & Cysteine synthase 2 & -3.56 & $\begin{array}{l}\text { Amino acid transport and } \\
\text { metabolism }\end{array}$ & None \\
\hline NCU04946 & Hypothetical protein & -3.73 & None & None \\
\hline NCU00436 & GTPase FZO1 & -4.11 & None & $\begin{array}{l}\text { Hydrolases. Acting on acid } \\
\text { anhydrides. Acting on } \\
\text { GTP; involved in cellular } \\
\text { and subcellular movement. }\end{array}$ \\
\hline NCU04781 & $\begin{array}{c}\text { NADH:Ubiquinone } \\
\text { Oxidoreductase } 9.8 \mathrm{kDa} \\
\text { Subunit }\end{array}$ & -4.23 & None & None \\
\hline NCU09345 & $\begin{array}{c}\text { Thiamine Biosynthesis } \\
\text { Protein NMT-1, Variant } 2\end{array}$ & -5.07 & $\begin{array}{c}\text { Inorganic ion transport and } \\
\text { metabolism }\end{array}$ & $\begin{array}{l}\text { Pyrimidine precursor } \\
\text { biosynthesis enzyme }\end{array}$ \\
\hline NCU06110 & $\begin{array}{c}\text { Thiazole Biosynthetic } \\
\text { Enzyme }\end{array}$ & -5.39 & $\begin{array}{c}\text { Coenzyme transport and } \\
\text { metabolism }\end{array}$ & $\begin{array}{c}\text { similar to stress-responsive } \\
\text { gene product }\end{array}$ \\
\hline NCU09143 & Hypothetical Protein & -5.72 & None & $\begin{array}{c}\text { F-Type ATP synthase } \\
\text { e-subunit }\end{array}$ \\
\hline NCU09460 & $\begin{array}{c}\text { NADH:Ubiquinone } \\
\text { Oxidoreductase } 20.1 \mathrm{kD} \\
\text { Subunit } \\
\end{array}$ & -5.86 & None & None \\
\hline NCU01024 & Hypothetical Protein & -6.45 & None & $\begin{array}{l}\text { Altered inheritance of } \\
\text { mitochondria protein } 5\end{array}$ \\
\hline
\end{tabular}




\begin{tabular}{|c|c|c|c|c|}
\hline \multicolumn{5}{|c|}{ Elevated in 238Por } \\
\hline $\begin{array}{l}\text { Accession } \\
\text { Number }\end{array}$ & Protein Description & $\begin{array}{c}\text { Expression } \\
\text { Difference } \\
\left(\log _{2}\right)\end{array}$ & COG Group & $\begin{array}{c}\text { Additional } \\
\text { Descriptions (KEGG) }\end{array}$ \\
\hline NCU01140 & $\begin{array}{l}\text { NAD(P) Trans } \\
\text { Hydrogenase }\end{array}$ & 3.91 & $\begin{array}{l}\text { Energy production and } \\
\text { conversion }\end{array}$ & None \\
\hline NCU05495 & $\begin{array}{l}\text { CVNH Domain- } \\
\text { Containing Protein }\end{array}$ & 3.47 & None & None \\
\hline NCU06546 & Hypothetical Protein & 2.84 & None & $\begin{array}{l}\text { K17983 sensitive to } \\
\text { high expression protein } \\
9\end{array}$ \\
\hline NCU05850 & $\begin{array}{l}\text { Rubredoxin-NAD } \\
\text { Reductase }\end{array}$ & 2.79 & General function prediction only & $\begin{array}{c}\text { Similar to pyridine } \\
\text { nucleotide-disulphide } \\
\text { oxidoreductase }\end{array}$ \\
\hline NCU00122 & $\begin{array}{c}\text { Aspartyl } \\
\text { Aminopeptidase }\end{array}$ & 2.52 & $\begin{array}{c}\text { Amino acid transport and } \\
\text { metabolism }\end{array}$ & None \\
\hline NCU09263 & $\begin{array}{c}\text { Anchored Cell Wall } \\
\text { Protein } 4 \\
\text { (Hypothetical) }\end{array}$ & 2.51 & None & None \\
\hline NCU07021 & $\begin{array}{c}\text { Peptide Chain Release } \\
\text { Factor } 3\end{array}$ & 2.36 & $\begin{array}{l}\text { Translation, ribosomal structure } \\
\text { and biogenesis }\end{array}$ & None \\
\hline NCU06880 & $\begin{array}{l}\text { AhpC/TSA Family } \\
\text { Protein }\end{array}$ & 2.23 & $\begin{array}{l}\text { Posttranslational modification, } \\
\text { protein turnover, chaperones }\end{array}$ & $\begin{array}{l}\text { Atypical 2-Cys } \\
\text { peroxiredoxin }\end{array}$ \\
\hline NCU03929 & Acyl-CoA Synthetase & 2.18 & Lipid transport and metabolism & Similar to Fum16p \\
\hline NCU03796 & $\begin{array}{c}\text { Pyruvate } \\
\text { Dehydrogenase Kinase }\end{array}$ & 2.17 & None & None \\
\hline NCU04578 & $\begin{array}{l}\text { ATP-Dependent Clp } \\
\text { Protease Proteolytic } \\
\text { Subunit }\end{array}$ & 2.16 & $\begin{array}{l}\text { Intracellular trafficking, } \\
\text { secretion, and vesicular transport }\end{array}$ & None \\
\hline NCU09285 & $\begin{array}{c}\text { Zinc-Containing } \\
\text { Alcohol } \\
\text { Dehydrogenase }\end{array}$ & 2.12 & General function prediction only & None \\
\hline NCU03006 & $\begin{array}{c}\text { Sterol 24-C- } \\
\text { Methyltransferase }\end{array}$ & 2.12 & $\begin{array}{c}\text { Coenzyme transport and } \\
\text { metabolism }\end{array}$ & None \\
\hline NCU16657 & $\begin{array}{l}\text { Tryptophanyl-tRNA } \\
\text { Synthetase }\end{array}$ & 2.11 & $\begin{array}{c}\text { Translation, ribosomal structure } \\
\text { and biogenesis }\end{array}$ & None \\
\hline NCU10021 & $\begin{array}{l}\text { MFS Monosaccharide } \\
\text { Transporter }\end{array}$ & 2.11 & None & None \\
\hline NCU05558 & $\begin{array}{l}\text { 3-Ketoacyl-CoA } \\
\text { Thiolase }\end{array}$ & 2.1 & Lipid transport and metabolism & None \\
\hline NCU06958 & $\begin{array}{l}\text { Mito Ribosomal } \\
\text { Protein S21 }\end{array}$ & 2.03 & None & None \\
\hline NCU02802 & $\begin{array}{c}\text { Mitochondrial } \\
\text { Ornithine Carrier } \\
\text { Protein }\end{array}$ & 1.98 & None & None \\
\hline NCU07858 & $\begin{array}{l}\text { DUF498 Domain- } \\
\text { Containing Protein }\end{array}$ & 1.94 & Function unknown & None \\
\hline NCU00264 & Hypothetical Protein & 1.91 & Signal transduction mechanisms & None \\
\hline \multicolumn{5}{|c|}{ Reduced in 238Por } \\
\hline NCU02936 & Proline Oxidase & -1.84 & None & None \\
\hline NCU06189 & $\begin{array}{l}\text { 5-Aminolevulinate } \\
\text { Synthase }\end{array}$ & -1.86 & $\begin{array}{l}\text { Coenzyme transport and } \\
\text { metabolism }\end{array}$ & None \\
\hline NCU00107 & $\begin{array}{l}\text { Mitochondrial Inner } \\
\text { Membrane Protease } \\
\text { ATP-23 }\end{array}$ & -2.41 & None & None \\
\hline NCU02504 & $\begin{array}{l}\text { DUF1640 Domain- } \\
\text { Containing protein }\end{array}$ & -2.62 & None & None \\
\hline NCU00565 & Lipoic Acid Synthetase & -2.82 & $\begin{array}{l}\text { Coenzyme transport and } \\
\text { metabolism }\end{array}$ & None \\
\hline
\end{tabular}




\begin{tabular}{|c|c|c|c|c|}
\hline NCU08354 & Hypothetical Protein & -2.84 & None & None \\
\hline NCU01024 & Hypothetical Protein & -2.9 & None & $\begin{array}{c}\text { altered inheritance of } \\
\text { mitochondria protein 5 }\end{array}$ \\
\hline NCU09143 & Hypothetical Protein & -3.93 & None & $\begin{array}{c}\text { F-type H+-transporting } \\
\text { ATP synthase e-subunit }\end{array}$ \\
\hline NCU04304 & $\begin{array}{c}\text { Outer Mitochondrial } \\
\text { Membrane Protein } \\
\text { Porin }\end{array}$ & -4.96 & None & $\begin{array}{c}\text { Voltage-dependent } \\
\text { anion channel protein 2 }\end{array}$ \\
\hline
\end{tabular}


Figure 1

A

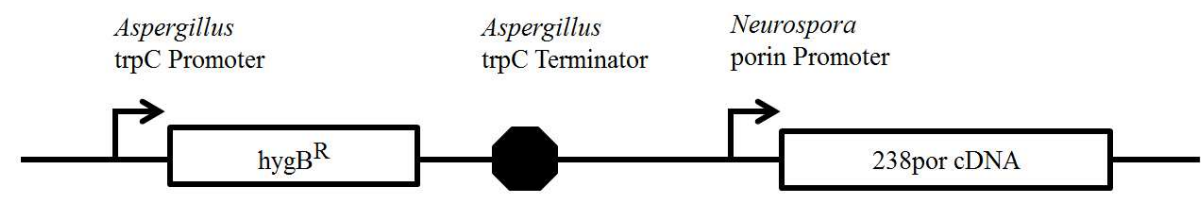

B

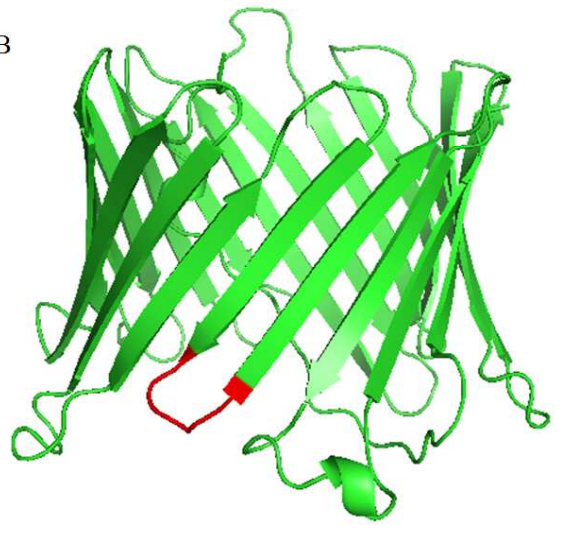

C

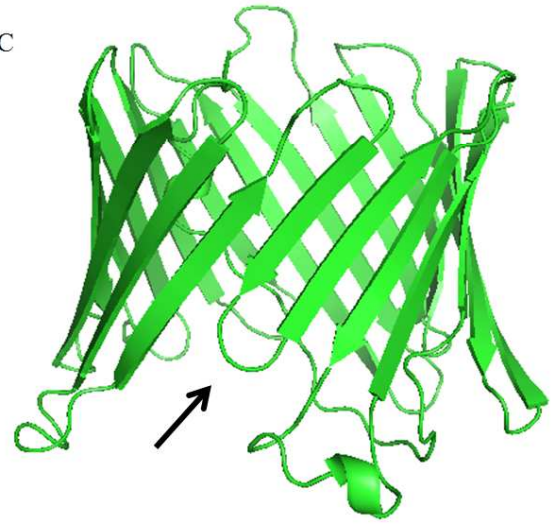

Figure 2

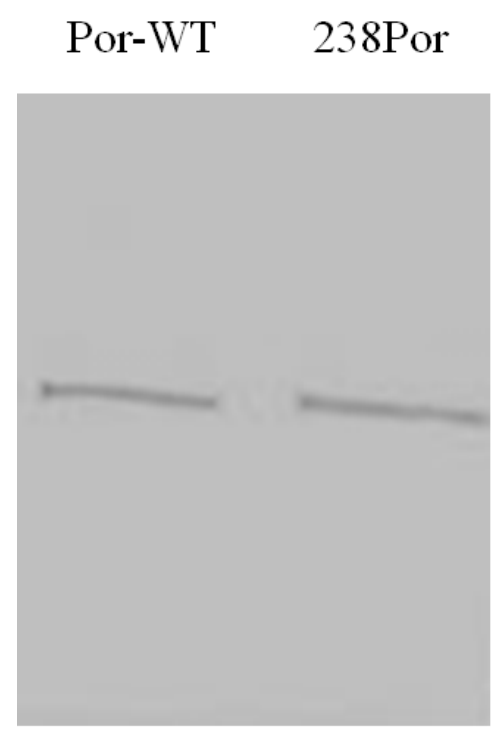

Tom70

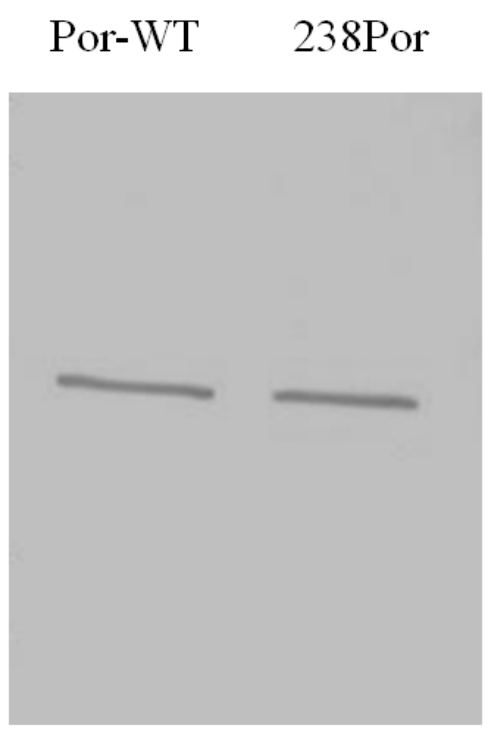

Tom 40

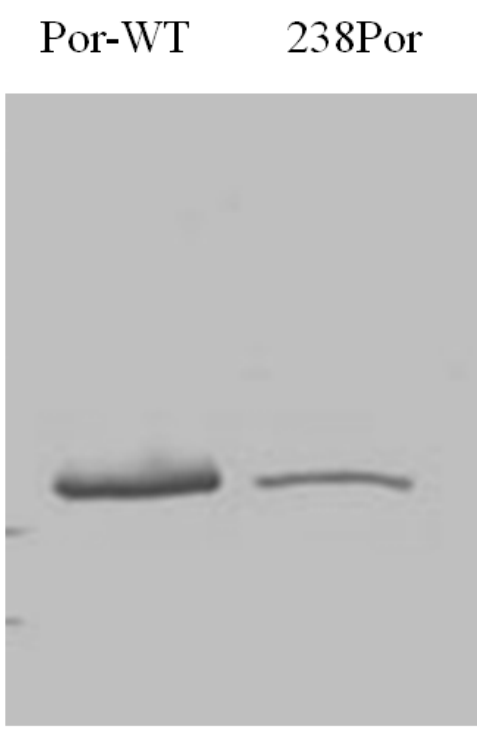

Por 
Figure 3

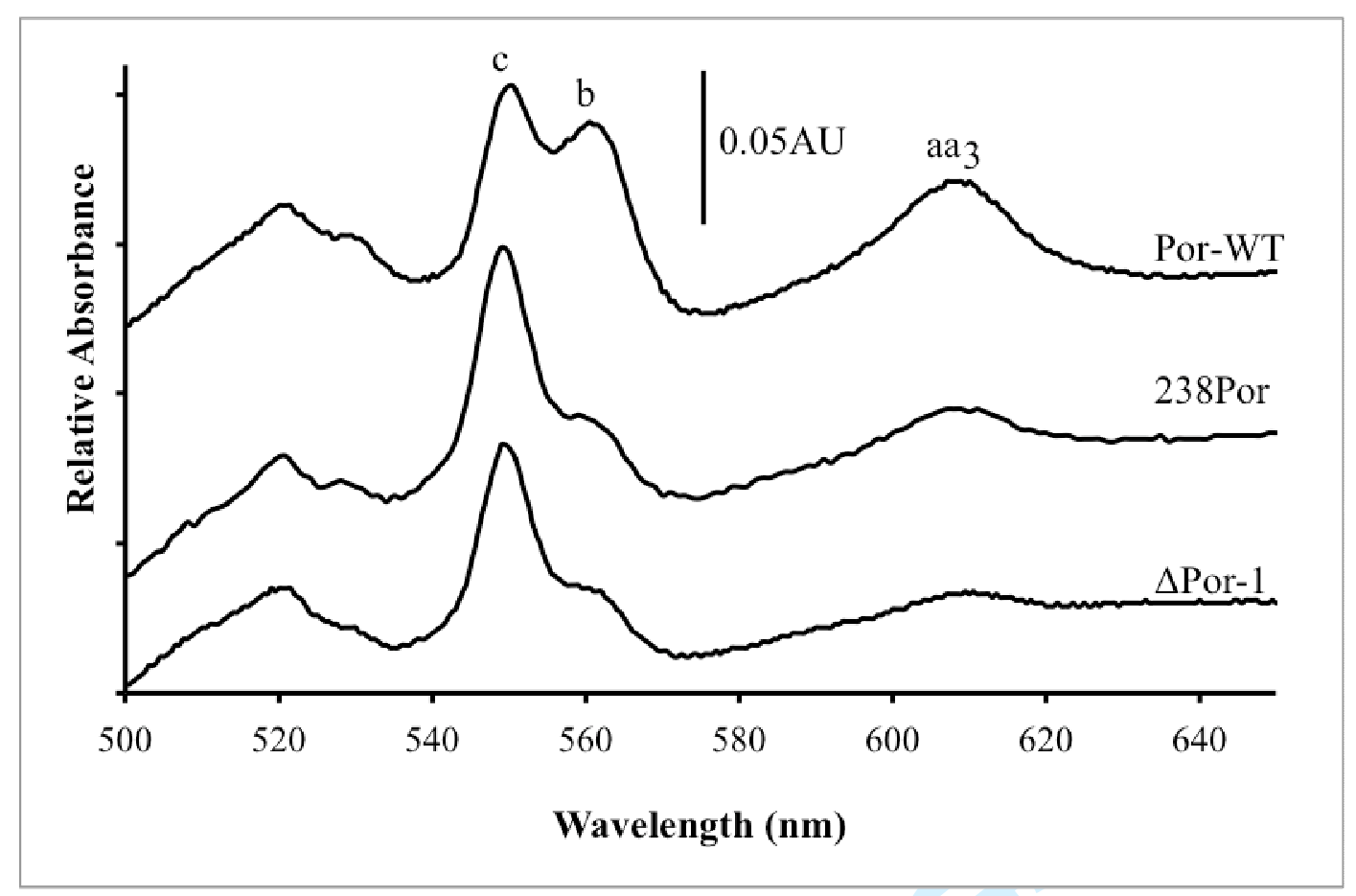


Figure 4

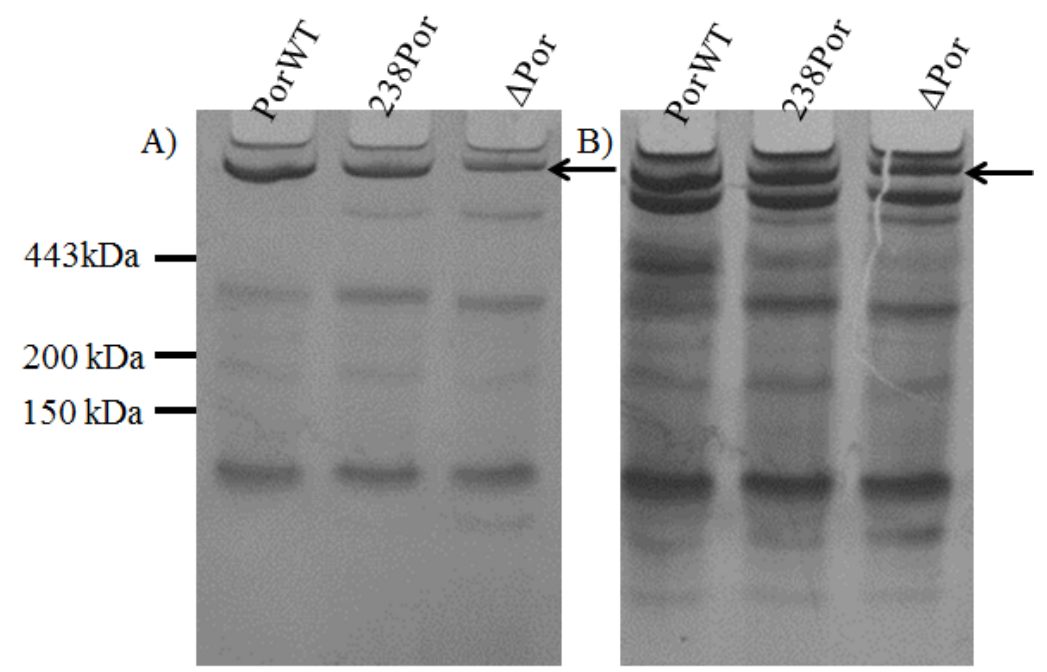


Figure 5

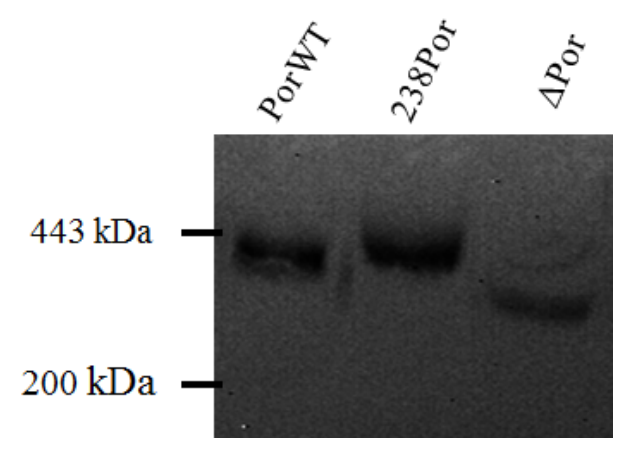

Figure 6

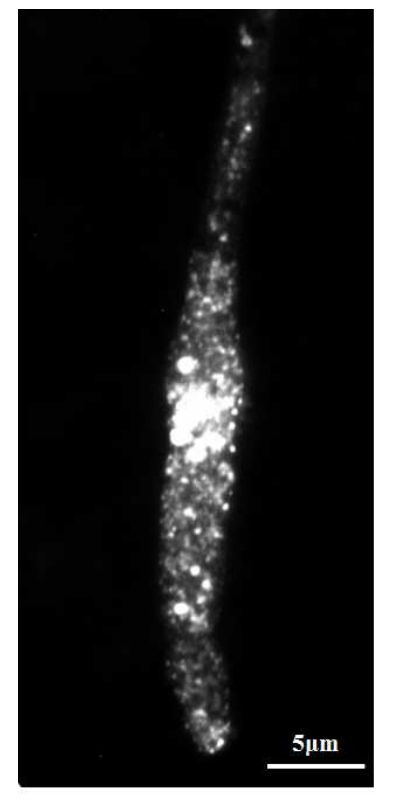

PorWT

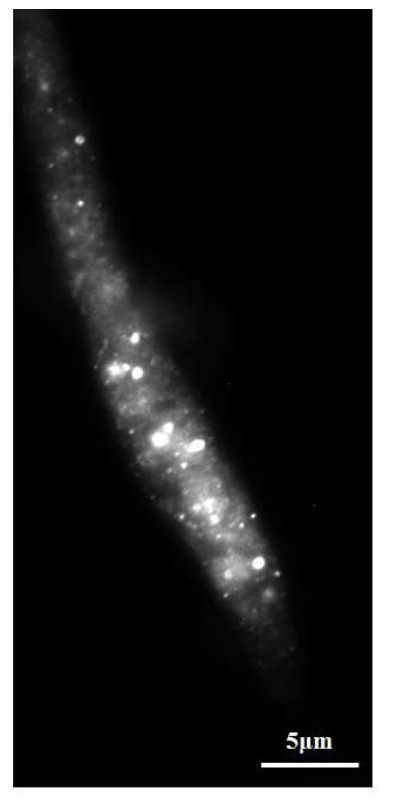

238Por

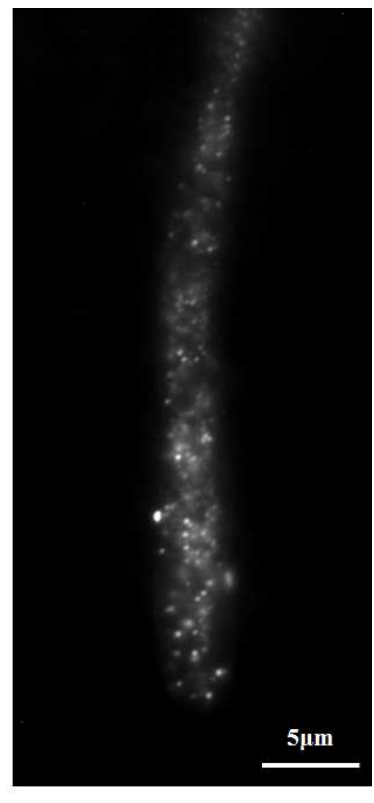

APor 


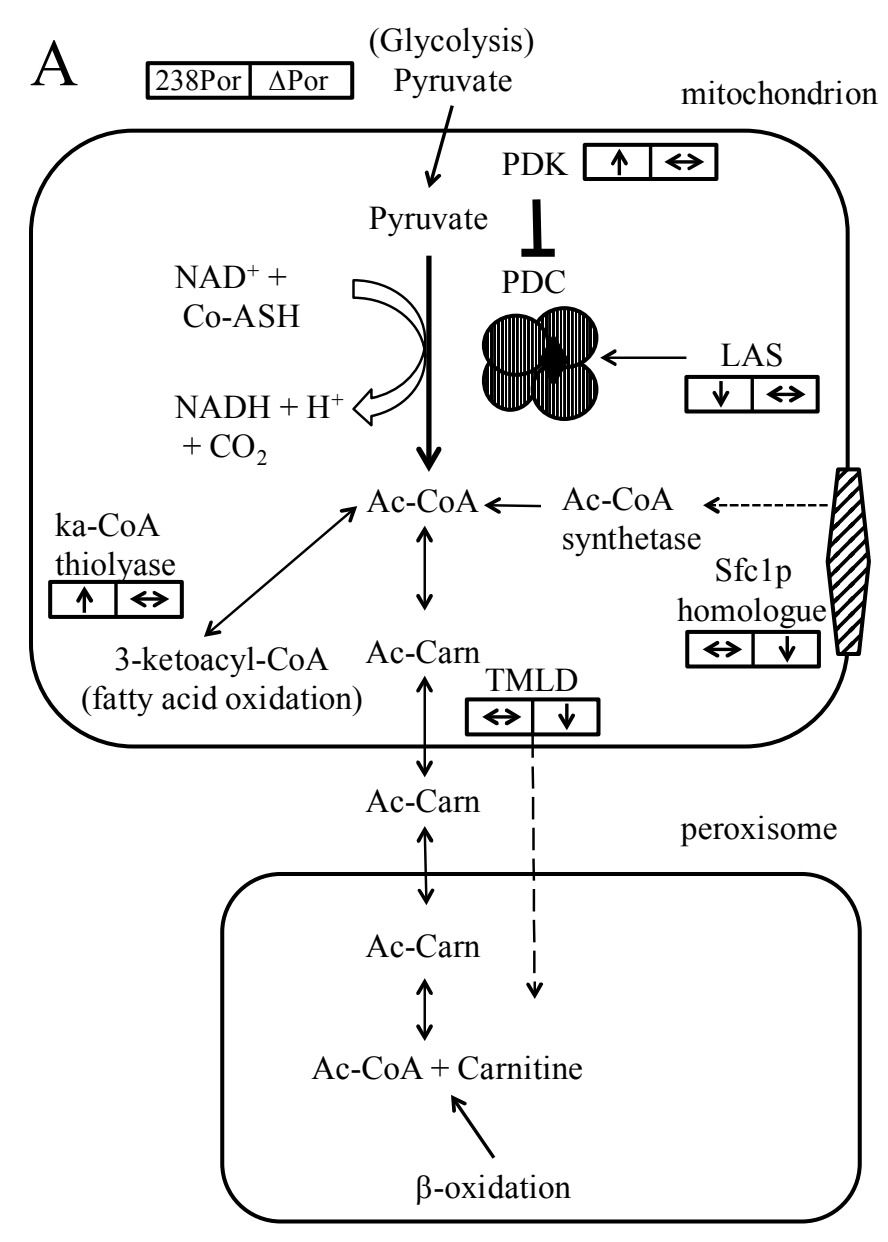

Figure 7

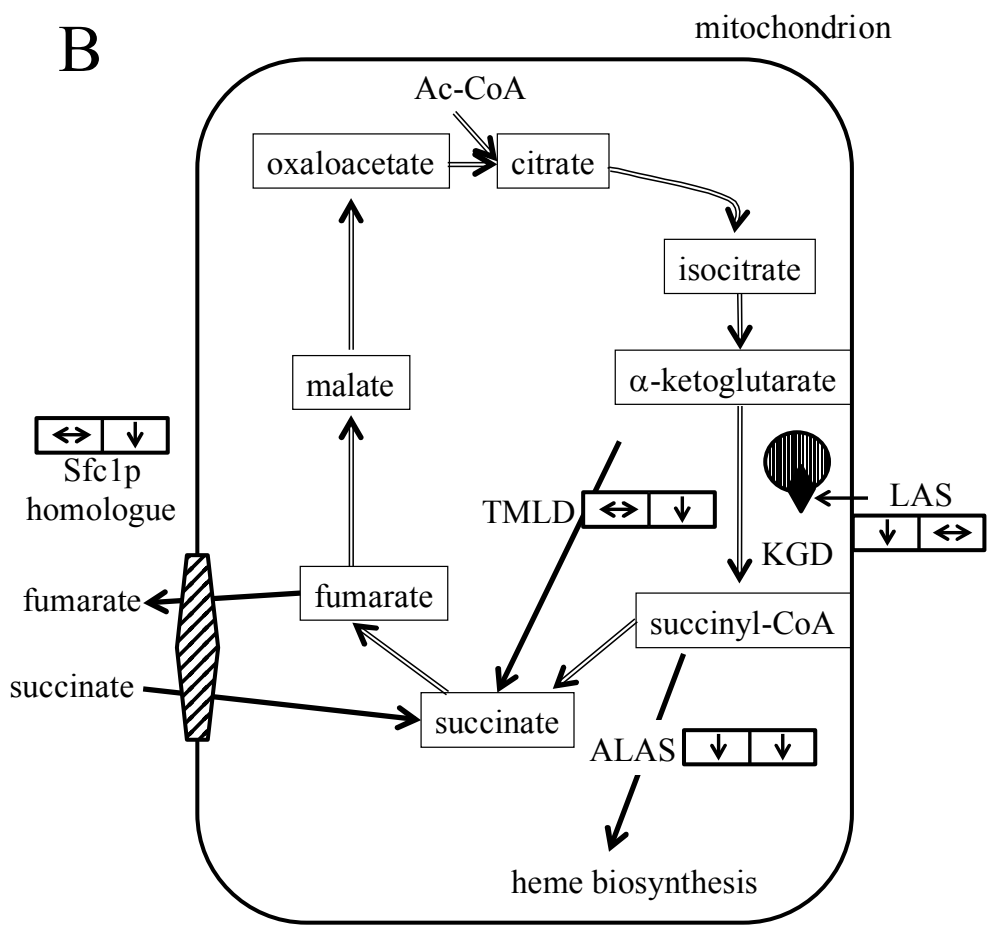


References

Bayrhuber, M., Meins, T., Habeck, M., Becker, S., Giller, K., Villinger, S., Vonrhein, C., Griesinger, C., Zweckstetter, M., and Zeth, K. 2008. Structure of the human voltage-dependent anion channel. Proc. Natl. Acad. Sci. U S A 105(40): $15370-15375$.

Benz, R. 1994. Permeation of hydrophilic solutes through mitochondrial outer membranes: review on mitochondrial porins. Biochim. Biophys. Acta 1197(2): 167-196.

Calvaruso, M.A., Smeitink, J., and Nijtmans, L. 2008. Electrophoresis techniques to investigate defects in oxidative phosphorylation. Methods 46(4): 281-287. doi: 10.1016/j.ymeth.2008.09.023.

Carneiro, P., Duarte, M., and Videira, A. 2004. The main external alternative NAD(P)H dehydrogenase of Neurospora crassa mitochondria. Biochim. Biophys. Acta 1608(1): 45-52.

Carneiro, P., Duarte, M., and Videira, A. 2007. The external alternative NAD(P)H dehydrogenase NDE3 is localized both in the mitochondria and in the cytoplasm of Neurospora crassa. J. Mol. Biol. 368(4): 1114-1121. doi:

10.1016/j.jmb.2007.02.080.

Carneiro, P., Duarte, M., and Videira, A. 2012. Characterization of apoptosis-related oxidoreductases from Neurospora crassa. PLoS One 7(3): e34270. doi: 10.1371/journal.pone.0034270.

Chatterjee, A., Abeydeera, N.D., Bale, S., Pai, P.J., Dorrestein, P.C., Russell, D.H., Ealick, S.E., and Begley, T.P. 2011. Saccharomyces cerevisiae THI4p is a suicide thiamine thiazole synthase. Nature 478(7370): 542-546. doi:

10.1038/nature10503.

Colombini, M. 2009. The published 3D structure of the VDAC channel: native or not? Trends Biochem. Sci. 34(8): $382-$ 389.

Colot, H.V., Park, G., Turner, G.E., Ringelberg, C., Crew, C.M., Litvinkova, L., Weiss, R.L., Borkovich, K.A., and Dunlap, J.C. 2006. A high-throughput gene knockout procedure for Neurospora reveals functions for multiple transcription factors. Proc. Natl. Acad. Sci. U S A 103(27): 10352-10357.

Court, D.A., Kleene, R., Neupert, W., and Lill, R. 1996. Role of the N- and C-termini of porin in import into the outer membrane of Neurospora mitochondria. FEBS Lett. 390(1): 73-77.

Davies, K.M., Anselmi, C., Wittig, I., Faraldo-Gomez, J.D., and Kuhlbrandt, W. 2012. Structure of the yeast F1Fo-ATP synthase dimer and its role in shaping the mitochondrial cristae. Proc. Natl. Acad. Sci. U S A 109(34): 13602-13607. doi: 10.1073/pnas. 1204593109 .

Davis, R.H., and De Serres, F.J. 1970. Genetic and microbiological research techniques for Neurospora crassa. Methods Enzymol. 17: 79-143.

Descheneau, A.T., Cleary, I.A., and Nargang, F.E. 2005. Genetic evidence for a regulatory pathway controlling alternative oxidase production in Neurospora crassa. Genetics 169(1): 123-135. doi: 10.1534/genetics.104.034017.

Drab, T., Kracmerova, J., Ticha, I., Hanzlikova, E., Ticha, M., and Liberda, J. 2011. Native polyacrylamide electrophoresis in the presence of Ponceau Red to study oligomeric states of protein complexes. J. Sep. Sci. 34(14): 16921695.

Duarte, M., Peters, M., Schulte, U., and Videira, A. 2003. The internal alternative NADH dehydrogenase of Neurospora crassa mitochondria. Biochem. J. 371(Pt 3): 1005-1011. doi: 10.1042/BJ20021374.

Dukanovic, J., and Rapaport, D. 2011. Multiple pathways in the integration of proteins into the mitochondrial outer membrane. Biochim. Biophys. Acta 1808(3): 971-980. 
Emanuelsson, O., Nielsen, H., Brunak, S., and von Heijne, G. 2000. Predicting subcellular localization of proteins based on their N-terminal amino acid sequence. J. Mol. Biol. 300(4): 1005-1016. doi: 10.1006/jmbi.2000.3903.

Fernandez, M., Fernandez, E., and Rodicio, R. 1994. ACR1, a gene encoding a protein related to mitochondrial carriers, is essential for acetyl-CoA synthetase activity in Saccharomyces cerevisiae. Mol. Gen. Genet. 242(6): 727-735.

Franken, J., Kroppenstedt, S., Swiegers, J.H., and Bauer, F.F. 2008. Carnitine and carnitine acetyltransferases in the yeast Saccharomyces cerevisiae: a role for carnitine in stress protection. Curr. Genet. 53(6): 347-360. doi: 10.1007/s00294-0080191-0.

Froschauer, E.M., Rietzschel, N., Hassler, M.R., Binder, M., Schweyen, R.J., Lill, R., Muhlenhoff, U., and Wiesenberger, G. 2013. The mitochondrial carrier Rim 2 co-imports pyrimidine nucleotides and iron. Biochem. J. 455(1): 57-65. doi: $10.1042 / \mathrm{BJ} 20130144$.

Funes, S., Nargang, F.E., Neupert, W., and Herrmann, J.M. 2004. The Oxa2 protein of Neurospora crassa plays a critical role in the biogenesis of cytochrome oxidase and defines a ubiquitous subbranch of the Oxa1/YidC/Alb3 protein family. Mol. Biol. Cell 15(4): 1853-1861. doi: 10.1091/mbc.E03-11-0789.

Gameiro, P.A., Laviolette, L.A., Kelleher, J.K., Iliopoulos, O., and Stephanopoulos, G. 2013. Cofactor balance by nicotinamide nucleotide transhydrogenase (NNT) coordinates reductive carboxylation and glucose catabolism in the tricarboxylic acid (TCA) cycle. J. Biol. Chem. 288(18): 12967-12977. doi: 10.1074/jbc.M112.396796.

Gattin, Z., Schneider, R., Laukat, Y., Giller, K., Maier, E., Zweckstetter, M., Griesinger, C., Benz, R., Becker, S., and Lange, A. 2015. Solid-state NMR, electrophysiology and molecular dynamics characterization of human VDAC2. J. Biomol. NMR 61(3-4): 311-320. doi: 10.1007/s10858-014-9876-5.

Goncalves, R.L., Rothschild, D.E., Quinlan, C.L., Scott, G.K., Benz, C.C., and Brand, M.D. 2014. Sources of superoxide/H2O2 during mitochondrial proline oxidation. Redox biology 2: 901-909. doi: 10.1016/j.redox.2014.07.003.

Gungormusler-Yilmaz, M., Shamshurin, D., Grigoryan, M., Taillefer, M., Spicer, V., Krokhin, O.V., Sparling, R., and Levin, D.B. 2014. Reduced catabolic protein expression in Clostridium butyricum DSM 10702 correlate with reduced 1,3propanediol synthesis at high glycerol loading. AMB Express 4: 63. doi: 10.1186/s13568-014-0063-6.

Hamon, M.P., Bulteau, A.L., and Friguet, B. 2015. Mitochondrial proteases and protein quality control in ageing and longevity. Ageing research reviews 23(Pt A): 56-66. doi: 10.1016/j.arr.2014.12.010.

Harkness, T.A., Metzenberg, R.L., Schneider, H., Lill, R., Neupert, W., and Nargang, F.E. 1994. Inactivation of the Neurospora crassa gene encoding the mitochondrial protein import receptor MOM19 by the technique of "sheltered RIP". Genetics 136(1): 107-118.

Hiller, S., Garces, R.G., Malia, T.J., Orekhov, V.Y., Colombini, M., Wagner, G. 2008. Solution structure of the integral human membrane protein VDAC-1 in detergent micelles. Science 321(5893):1206-1210.

Homblé, F., Krammer, E.M., and Prevost, M. 2012. Plant VDAC: facts and speculations. Biochim. Biophys. Acta 1818(6): 1486-1501.

Hoppins, S., Collins, S.R., Cassidy-Stone, A., Hummel, E., Devay, R.M., Lackner, L.L., Westermann, B., Schuldiner, M., Weissman, J.S., and Nunnari, J. 2011. A mitochondrial-focused genetic interaction map reveals a scaffold-like complex required for inner membrane organization in mitochondria. J Cell Biol 195(2): 323-340. doi: 10.1083/jcb.201107053.

Hunter, G.A., and Ferreira, G.C. 2011. Molecular enzymology of 5-aminolevulinate synthase, the gatekeeper of heme biosynthesis. Biochim. Biophys. Acta 1814(11): 1467-1473. doi: 10.1016/j.bbapap.2010.12.015.

Keeping, A., Deabreu, D., Dibernardo, M., and Collins, R.A. 2011. Gel-based mass spectrometric and computational approaches to the mitochondrial proteome of Neurospora. Fungal Genet. Biol. 48(5): 526-536. 
Kelley, L.A., and Sternberg, M.J. 2009. Protein structure prediction on the Web: a case study using the Phyre server. Nat. Protoc. 4(3): 363-371. doi: 10.1038/nprot.2009.2.

Klanner, C., Prokisch, H., and Langer, T. 2001. MAP-1 and IAP-1, two novel AAA proteases with catalytic sites on opposite membrane surfaces in mitochondrial inner membrane of Neurospora crassa. Mol. Biol. Cell 12(9): 2858-2869.

Kurashima, K., Chae, M., Inoue, H., Hatakeyama, S., and Tanaka, S. 2013. A uvs-5 strain is deficient for a mitofusin gene homologue, fzo1, involved in maintenance of long life span in Neurospora crassa. Eukaryot. Cell 12(2): 233-243. doi: 10.1128/EC.00226-12.

Lambowitz, A.M., and Slayman, C.W. 1971. Cyanide-resistant respiration in Neurospora crassa. J. Bacteriol. 108(3): 1087-1096.

Lee, H.C., and Zhang, L. 2009. A unique mechanism of chaperone action: heme regulation of Hap1 activity involves separate control of repression and activation. Protein Pept. Lett. 16(6): 642-649.

Lemaire, C., Guibet-Grandmougin, F., Angles, D., Dujardin, G., and Bonnefoy, N. 2004. A yeast mitochondrial membrane methyltransferase-like protein can compensate for oxal mutations. J. Biol. Chem. 279(46): 47464-47472. doi: 10.1074/jbc.M404861200.

Malki, A., Caldas, T., Abdallah, J., Kern, R., Eckey, V., Kim, S.J., Cha, S.S., Mori, H., and Richarme, G. 2005. Peptidase activity of the Escherichia coli Hsp31 chaperone. J. Biol. Chem. 280(15): 14420-14426. doi: 10.1074/jbc.M408296200.

Marques, I., Duarte, M., and Videira, A. 2003. The $9.8 \mathrm{kDa}$ subunit of complex I, related to bacterial Na(+)-translocating NADH dehydrogenases, is required for enzyme assembly and function in Neurospora crassa. J. Mol. Biol. 329(2): 283290.

Maxwell, D.P., Wang, Y., and McIntosh, L. 1999. The alternative oxidase lowers mitochondrial reactive oxygen production in plant cells. Proc. Natl. Acad. Sci. U S A 96(14): 8271-8276.

McCluskey, K., Wiest, A., and Plamann, M. 2010. The Fungal Genetics Stock Center: a repository for 50 years of fungal genetics research. J. Biosci. 35(1): 119-126.

Messerschmitt, M., Jakobs, S., Vogel, F., Fritz, S., Dimmer, K.S., Neupert, W., and Westermann, B. 2003. The inner membrane protein Mdm33 controls mitochondrial morphology in yeast. J. Cell Biol. 160(4): 553-564. doi:

$10.1083 /$ jcb.200211113.

Morikawa, T., Yasuno, R., and Wada, H. 2001. Do mammalian cells synthesize lipoic acid? Identification of a mouse cDNA encoding a lipoic acid synthase located in mitochondria. FEBS Lett. 498(1): 16-21.

Palmieri, L., Agrimi, G., Runswick, M.J., Fearnley, I.M., Palmieri, F., and Walker, J.E. 2001. Identification in Saccharomyces cerevisiae of two isoforms of a novel mitochondrial transporter for 2-oxoadipate and 2-oxoglutarate. J. Biol. Chem. 276(3): 1916-1922. doi: 10.1074/jbc.M004332200.

Petersen Shay, K., Moreau, R.F., Smith, E.J., and Hagen, T.M. 2008. Is alpha-lipoic acid a scavenger of reactive oxygen species in vivo? Evidence for its initiation of stress signaling pathways that promote endogenous antioxidant capacity. IUBMB Life 60(6): 362-367. doi: 10.1002/iub.40.

Popov-Celeketic, J., Waizenegger, T., and Rapaport, D. 2008. Mim1 functions in an oligomeric form to facilitate the integration of Tom20 into the mitochondrial outer membrane. J. Mol. Biol. 376(3): 671-680. doi:

10.1016/j.jmb.2007.12.006.

Rifkin, M.R., and Luck, D.J. 1971. Defective production of mitochondrial ribosomes in the poky mutant of Neurospora crassa. Proc. Natl. Acad. Sci. U S A 68(2): 287-290. 
Roman, I., Figys, J., Steurs, G., and Zizi, M. 2005. In vitro interactions between the two mitochondrial membrane proteins VDAC and cytochrome c oxidase. Biochemistry 44(39): 13192-13201.

Runke, G., Maier, E., Summers, W.A.T., Bay, D.C., Benz, R., and Court, D.A. 2006. Deletion variants of Neurospora mitochondrial porin: Electrophysiological and spectroscopic analysis. Biophys. J. 90: 3155-3164.

Schmitt, S., Prokisch, H., Schlunck, T., Camp, D.G., 2nd, Ahting, U., Waizenegger, T., Scharfe, C., Meitinger, T., Imhof, A., Neupert, W., Oefner, P.J., and Rapaport, D. 2006. Proteome analysis of mitochondrial outer membrane from Neurospora crassa. Proteomics 6(1): 72-80.

Schonauer, M.S., Kastaniotis, A.J., Kursu, V.A., Hiltunen, J.K., and Dieckmann, C.L. 2009. Lipoic acid synthesis and attachment in yeast mitochondria. J. Biol. Chem. 284(35): 23234-23242. doi: 10.1074/jbc.M109.015594.

Schredelseker, J., Paz, A., Lopez, C.J., Altenbach, C., Leung, C.S., Drexler, M.K., Chen, J.N., Hubbell, W.L., and Abramson, J. 2014. High resolution structure and double electron-electron resonance of the zebrafish voltage-dependent anion channel 2 reveal an oligomeric population. J. Biol. Chem. 289(18): 12566-12577. doi: 10.1074/jbc.M113.497438.

Scranton, M.A., Yee, A., Park, S.Y., and Walling, L.L. 2012. Plant leucine aminopeptidases moonlight as molecular chaperones to alleviate stress-induced damage. J. Biol. Chem. 287(22): 18408-18417. doi: 10.1074/jbc.M111.309500.

Seo, M.S., Kang, S.W., Kim, K., Baines, I.C., Lee, T.H., and Rhee, S.G. 2000. Identification of a new type of mammalian peroxiredoxin that forms an intramolecular disulfide as a reaction intermediate. J. Biol. Chem. 275(27): 20346-20354. doi: 10.1074/jbc.M001943200.

Sherman, E.L., Taylor, R.D., Go, N.E., and Nargang, F.E. 2006. Effect of mutations in Tom40 on stability of the translocase of the outer mitochondrial membrane (TOM) complex, assembly of Tom40, and import of mitochondrial preproteins. J. Biol. Chem. 281(32): 22554-22565.

Shoshan-Barmatz, V., and Mizrachi, D. 2012. VDAC1: from structure to cancer therapy. Frontiers in oncology 2: 164. doi: $10.3389 /$ fonc. 2012.00164 .

Staben, C., Jensen, B., Singer, M., Pollock, J., Schechtman, M., Kinsey, J., and Selker, E.U. 1989. Use of a bacterial Hygromycin B resistance gene as a dominant selectable marker in Neurospora crassa transformation. Fungal Genet. Newsl. 36: 79-81.

Strijbis, K., van Roermund, C.W., Visser, W.F., Mol, E.C., van den Burg, J., MacCallum, D.M., Odds, F.C., Paramonova, E., Krom, B.P., and Distel, B. 2008. Carnitine-dependent transport of acetyl coenzyme A in Candida albicans is essential for growth on nonfermentable carbon sources and contributes to biofilm formation. Eukaryot. Cell 7(4): 610-618. doi: 10.1128/EC.00017-08.

Summers, W.A., and Court, D.A. 2010. Origami in outer membrane mimetics: correlating the first detailed images of refolded VDAC with over 20 years of biochemical data. Biochem. Cell Biol. 88(3): 425-438.

Summers, W.A., Wilkins, J.A., Dwivedi, R.C., Ezzati, P., and Court, D.A. 2012. Mitochondrial dysfunction resulting from the absence of mitochondrial porin in Neurospora crassa. Mitochondrion 12(2): 220-229. doi:

10.1016/j.mito.2011.09.002.

Tanton, L.L., Nargang, C.E., Kessler, K.E., Li, Q., and Nargang, F.E. 2003. Alternative oxidase expression in Neurospora crassa. Fungal Genet. Biol. 39(2): 176-190.

Tetaud, E., Godard, F., Giraud, M.F., Ackerman, S.H., and di Rago, J.P. 2014. The depletion of F(1) subunit epsilon in yeast leads to an uncoupled respiratory phenotype that is rescued by mutations in the proton-translocating subunits of F(0). Mol. Biol. Cell 25(6): 791-799. doi: 10.1091/mbc.E13-02-0112. 
Ujwal, R., Cascio, D., Colletier, J.P., Faham, S., Zhang, J., Toro, L., Ping, P., and Abramson, J. 2008. The crystal structure of mouse VDAC1 at 2.3 A resolution reveals mechanistic insights into metabolite gating. Proc. Natl. Acad. Sci. U S A 105(46): 17742-17747.

Wagner, K., Rehling, P., Sanjuan Szklarz, L.K., Taylor, R.D., Pfanner, N., and van der Laan, M. 2009. Mitochondrial F1Fo-ATP synthase: the small subunits e and $\mathrm{g}$ associate with monomeric complexes to trigger dimerization. J. Mol. Biol. 392(4): 855-861. doi: 10.1016/j.jmb.2009.07.059.

Wideman, J.G., Go, N.E., Klein, A., Redmond, E., Lackey, S.W., Tao, T., Kalbacher, H., Rapaport, D., Neupert, W., and Nargang, F.E. 2010. Roles of the Mdm10, Tom7, Mdm12, and Mmm1 proteins in the assembly of mitochondrial outer membrane proteins in Neurospora crassa. Mol. Biol. Cell. 21(10): 1725-1736.

Young, M.J., Bay, D.C., Hausner, G., and Court, D.A. 2007. The evolutionary history of mitochondrial porins. BMC Evol. Biol. 7: 31 .

Zeng, X., Kucharczyk, R., di Rago, J.P., and Tzagoloff, A. 2007. The leader peptide of yeast Atp6p is required for efficient interaction with the Atp9p ring of the mitochondrial ATPase. J. Biol. Chem. 282(50): 36167-36176. doi: $10.1074 /$ jbc.M705436200.

Zhang, S., Hulver, M.W., McMillan, R.P., Cline, M.A., and Gilbert, E.R. 2014. The pivotal role of pyruvate dehydrogenase kinases in metabolic flexibility. Nutr. Metabolism 11(1): 10. doi: 10.1186/1743-7075-11-10. 